\title{
DETERMINANTS FOR COOPETITION STRATEGIES OF INTERNATIONAL JOINT VENTURES IN HIGH-SPEED RAILWAY PROJECTS
}

\author{
Yanliang NIU1, Dan $\mathrm{ZHAO}^{1}$, Xiaopeng DENG ${ }^{2}$, Ruoyu LU ${ }^{3}$, Xianbo ZHAO ${ }^{\star}$ \\ ${ }^{1}$ School of Economics and Management, Shijiazhuang Tiedao University, 15 Beierhuan East Road, \\ Shijiazhuang 050043, China \\ ${ }^{2}$ School of Civil Engineering, Southeast University, 2 Southeast University Road, Nanjing 211189, China \\ ${ }^{3}$ Heinz College, Carnegie Mellon University, 5000 Forbes Avenue, Pittsburgh 15213-3890, USA \\ ${ }^{4}$ School of Engineering and Technology, Central Queensland University, 400 Kent Street, \\ Sydney, NSW 2000, Australia
}

Received 16 February 2021; accepted 18 May 2021

\begin{abstract}
International joint ventures (IJVs) have become a significant mode of exploiting high-speed railway (HSR) overseas market for contractors. This study is devoted to identify the determinants for the coopetition strategies of IJVs in the HSR projects, as well as the interactive paths. On the base of a thorough literature review and the pilot study with five industry experts, 22 determinants were identified and packaged into six groups covering the three levels (including macro, firm, and project levels). Meanwhile, the interactive paths amongst the six groups were proposed. A questionnaire survey was performed with 210 practitioners experienced in IJVs in HSR projects to assess the significance of the factors, and 113 valid questionnaires were received. Based on the collected data, six groups of 22 determinants and nine interactive paths were verified by applying partial least-squares structural equation modeling technology. Specifically, these significant paths could be classified into two categories, namely the coopetition-capability oriented paths, and the coopetition-relationship oriented paths. The findings of this paper are conductive to expand the knowledge on coopetition and provide a useful reference for the members of IJVs in HSR projects to accomplish coopetition strategies from pre-project phase, the implementation phase, to post-project phase.
\end{abstract}

Keywords: high-speed railway, international joint ventures, coopetition strategies, determinants.

\section{Introduction}

High-speed railway (HSR) is a fast, convenient, and green transportation, so more and more countries have been making HSR plans (Chou et al., 2012; Niu et al., 2019). As of February 2020, the total length of HSR worldwide is $52484 \mathrm{~km}$ in operation, $11960 \mathrm{~km}$ under construction, $11383 \mathrm{~km}$ of an approved plan, and $28586 \mathrm{~km}$ of longterm planning (Union Internationale des Chemins de fer [UIC], 2020). Figure 1 shows the mileage of HSR under construction, planned construction, and long-term planning in major areas, including Africa, Asia Pacific, Europe, Middle-east, North America, and Latin America (UIC, 2020).

However, facing the increasing HSR demand in the international market, the HSR contractors should choose the appropriate mode to exploit the overseas market. According to the previous international HSR projects, the mode of international joint ventures (IJVs) has being widely used, such as in the Jakarta-Bandung HSR project and the Ankara-Istanbul HSR II project (Hong \& Chan, 2014; Zhang et al., 2019, 2020b). This paper defines the IJVs as the marriage between at least two firms from the HSR industry joining forces together in pursuit of HSR projects, and the mode of IJVs includes two systems, namely the contractual IJVs system and the equity IJVs system (Girmscheid \& Brockmann, 2010). If the IJVs regulated by both the IJVs contract and the contract signed with the client, it is the contractual IJVs system. While the equity IJVs system is a new organization relatively independent of its parent firms (Tetteh \& Chan, 2019). The above two IJVs systems in HSR projects have two common features. One feature is that the IJVs are cross-border due to the members from different countries (Girmscheid

*Corresponding author. E-mail: b.zhao@cqu.edu.au 


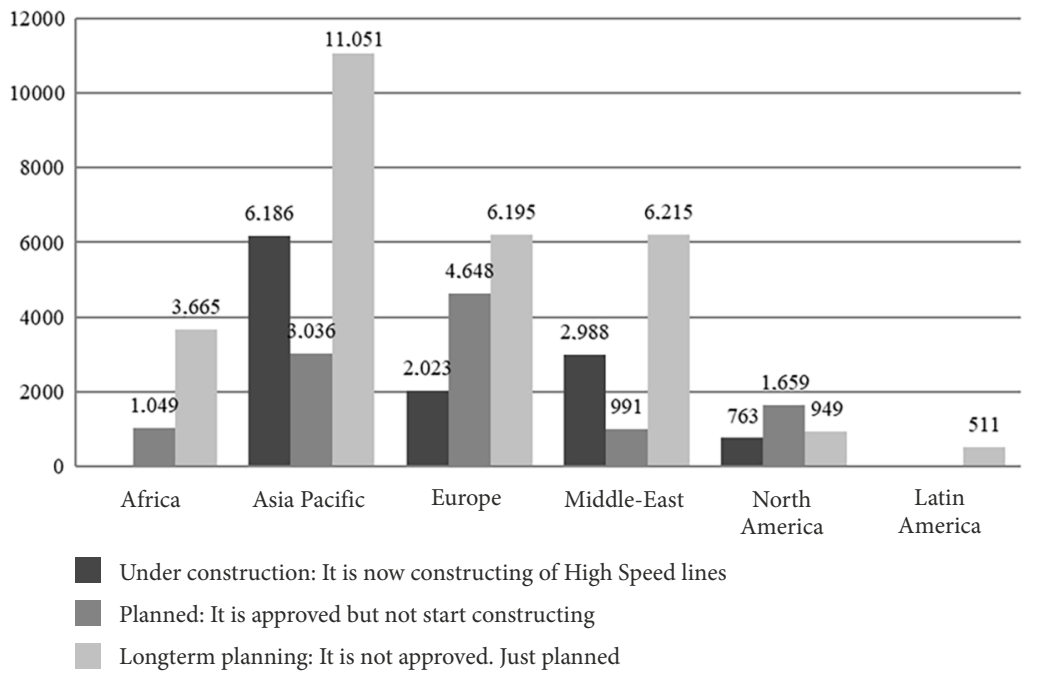

Figure 1. HSR Mileages in major areas (unit: kilometers)

\& Brockmann, 2010). The other feature is that the IJVs are associated with cross-industry issues, because based on the UIC report, the HSR system is divided into five subsystems: infrastructure, track, energy, control-command and signaling, and rolling stock, which shows that the HSR industry system is integrated and complex (UIC, 2018; Ivaldi \& Pouyet, 2018; Zhou et al., 2019). It requires that the members should have diversified industry backgrounds. The features make the HSR IJVs differ from the IJVs for other kinds of projects (Zhang et al., 2020b; Niu et al., 2019).

The cross-border and cross-industry features of IJVs fortify the complexity of the relationship among the members, including competition and cooperation. Some studies have concentrated on the cooperation among the members of IJVs, such as risk-sharing and management (Zhao et al., 2013; Hwang et al., 2013, 2016), and performance evaluation (Ozorhon et al., 2008a, 2008b, 2011; Tetteh et al., 2019), etc. At the same time, there is also competition among the members of IJVs, such as the distribution of benefits (McIntosh \& McCabe, 2003), the transfer of technology (Zhang et al., 2010), and the resolution of conflicts (Maemura et al., 2018). However, Bilotkach and Hüschelrath (2019) insisted that the competition and cooperation among the members of IJVs denotes the relationship simultaneously, which echoes the concept of coopetition proposed by Brandenburger and Nalebuff (1996).

How can the members of IJVs thrive when engaging in coopetition activities? Coopetition Strategy, one of the revolutionary mindsets, will help achieve mutual win-win situations (Brandenburger \& Nalebuff, 1996). For example, Hannah and Eisenhardt (2018) identified three distinct coopetition strategies through a case study of five firms in the U.S. residential solar industry, which help them survive in nascent ecosystems through time effectively.

However, many factors determine whether the coopetition strategy can be effectively implemented, thus it is necessary to identify these determinants. For instance,
Chin et al. (2008) identified and prioritized the determinants of coopetition strategy in Hong Kong's manufacturing industry, providing valuable information for the realization of resource integration among competitors. There are also studies trying to investigate the factors for coopetition strategies from other perspectives, such as between departments within small businesses (Thomason et al., 2013), and between manufacturers and suppliers (Tidström \& Rajala, 2016). Nevertheless, these studies failed to: (1) focus on cooperation and competition simultaneously among members of IJVs in HSR projects; (2) analyze the determinants for coopetition strategies on the acrosslevel (macro, firm, and project level); (3) reveal the interactive paths of determinants for coopetition strategies.

To bridge the knowledge gap, this paper intends to investigate the determinants for the coopetition strategies of IJVs in HSR projects. Specifically, the research questions are: (i) what factors determine the coopetition strategies of IJVs in HSR projects at the macro, firm, and project level; and (ii) what is the relationship among these factor groups. The results of this study would contribute to the coopetition theory in the field of HSR projects by providing a framework of determinants for coopetition strategies involving macro, firm, and project levels. Also, this paper would provide the members of IJVs with guidance to understand the nature of the determinants for coopetition strategies so that they can investigate their current situations for optimizing the coopetition strategies.

\section{Literature review}

\subsection{What's coopetition?}

Coopetition is a combination of competition and cooperation among firms proposed by Brandenburger and Nalebuff (1996) for the first time. According to Brandenburger and Nalebuff (1996), there was no pure competition or cooperation between firms, and it is necessary to consider the two aspects as a syncretized thing. On this basis, the 
topic of coopetition has attracted more and more attention, and formed two perspectives. For one perspective, some scholars tended to regard the coopetition as an integration of competition and cooperation (Gnyawali \& Madhavan, 2001). For example, Afuah (2000) proposed an integrative coopetition analysis framework that includes customers, suppliers, competitors, and complementors. Furthermore, Gnyawali and Madhavan (2001) attributed the integration of competition and cooperation to the mutual influence and the dependence of resources among firms in the social network. For the other perspective, some researches on coopetition considered the competition and cooperation between firms as isolated or even mutually opposite parties, as well as conducted a dichotomy study (Bengtsson \& Kock, 2000). For instance, when creating the demand in a market, the manifestation of business is often cooperation, while when distributing the profit, the manifestation is often competition (Bengtsson \& Raza-Ullah, 2016). Similarly, J. M. Crick and D. Crick (2020) proposed the Yin and Yang concept from the Chinese philosophy to explain the coopetition as a paradoxical relationship of cooperation and competition, and it would be harmful to the firms without effective management. Moreover, Crick (2019) discussed that "too little" or "too much" coopetition was bad for firms, and that only optimal coopetition can generate benefits for the firms, including improvement of performance (Dorn et al., 2016), enhancement of innovation capability (Park et al., 2014), and knowledge sharing (Levy et al., 2003). Therefore, when engaging in coopetition, it is necessary to balance the relationship of competition and cooperation between firms by implementing coopetition strategies (Zhang et al., 2020a).

Coopetition strategies are influenced by a variety of factors for different industries and regions. Chin et al. (2008) identified and prioritized determinants for coopetition strategies in the Hong Kong manufacturing industry. Thomason et al. (2013) proposed the determinants of successful coopetition strategies applications in small businesses, including individuals, firms, dyadic, and triadic relationship levels. Also, Mariani (2007) illustrated the role played by the external environment in triggering coopetition strategies.

Coopetition strategy is a multidimensional and multifaceted concept (Chin et al., 2008), in its application should pay attention to the coopetition relationship (Dyer et al., 2018; Luo, 2004), but also pay attention to the coopetition capability (Luo, 2005; Quintana-García \& Benavides-Velasco, 2004). Indeed, previous research has always been paid attention to the coopetition relationship or coopetition capability independently, failing to bring the coopetition relationship and capability together. Several studies proposed the concept of the coopetition relationship, while they assumed that the firms create value in alliances when they establish of coopetition relationship (Wilhelm, 2011; Luo, 2007). Moreover, the coopetition capability was considered a kind of capability obtained in the process of competition and cooperation among firms (Cozzolino \& Rothaerme, 2018). Due to the interplay between coopetition relationship and capability has remained under-researched, it is necessary to highlight the association between the two.

\subsection{Coopetition in IJVs for HSR projects}

HSR projects have attracted great attention from researchers. To date, much of the literature on HSR competition has involved the industry level (Niu et al., 2020), the firm level (Zhang et al., 2019, 2020b), and the project level (Zhou et al., 2019; Niu et al., 2019). In addition, Niu et al. (2021) explored the interactive paths covering three levels (project, firm, and industry levels) of the international competitive advantages for HSR contractors. Apparently, competition on the HSR project includes cross-industry subjects like planning and design, civil construction, equipment manufacturing, communication control, operation, and finance (Niu et al., 2019). For giving full play to the advantages of the industrial chain, HSR contractors are willing to cooperate with other types of firms within the HSR industry and to form the IJVs (Ivaldi \& Pouyet, 2018; Zhou et al., 2019).

Nevertheless, the existing research on IJVs has not considered competition or cooperation among members as a unified whole. A relatively large amount of research has focused on competition among members of the IJVs related to the distribution of benefits (McIntosh \& McCabe, 2003; Antolín-López et al., 2016), dispute resolution mechanisms (Maemura et al., 2018; Chan \& Suen, 2005), technology transfer (Ganesan \& Kelseey, 2006; Zhang et al., 2010), etc. For example, Antolín-López et al. (2016) performed an in-depth study comparing the contributions of different stakeholders by establishing a system of indicators. A more recent study by Tetteh et al. (2020) explicitly confirmed that the conflicts as one of the top 10 barrier factors jeopardized IJVs success. And the function of IJVs as tools for the transfer of technology and knowledge has been highlighted by Ganesan and Kelsey (2006).

While focusing on the cooperation among the members of IJVs, some research concentrated on risk-sharing and management (Zhao et al., 2013; Hwang et al., 2016; Tetteh et al., 2020). For example, Tetteh et al. (2020) identified six groups of 53 risk factors and proposed a conceptual framework for managing risks in IJVs operation. Additionally, some research concentrated on the cooperation performance of IJVs (Ozorhon et al., 2008a, 2008b, 2011; Tetteh et al., 2019). According to Ozorhon et al. (2008a), there were several factors influencing the performance of international construction joint ventures. However, there is an absence of research focusing on both competition and cooperation among members of the IJVs at the same time.

In the current studies related to the combination of coopetition and IJVs, one of the critical topics is the determinants exploration. Chan et al. (2004) and Cheng et al. (2000) identified and established determinants for partnering projects, which are valuable for formulating 
effective coopetition strategies. Furthermore, the relationship among determinants needs to be further explored to help members of IJVs better understand the nature of determinants. For example, Cheng et al. (2000) explored the underlying interrelationship among determinants for construction projects to help managers achieve project success. However, there is a lack of research on the interrelationship among determinants for coopetition strategies, due to the constraints of a variety of statistical techniques (Li et al., 2005; Toor \& Ogunlana, 2008), which entails difficulties for managers to accomplish coopetition.

In view of the importance of coopetition, this study aims to identify determinants for coopetition strategies of IJVs in HSR projects. According to the above relative literature, there are more than 100 studies, of which 11 are the most relevant. Finally, a total of 22 determinants from the three levels (including macro, firm, and project) were identified and encoded from F01 to F22, which were divided into six groups (see Table 1).
After the classification of the 22 determinants, the potential relationship among the six groups was also identified from the related literature. In this path model, there are two kinds of paths. The one is the coopetition-relationship oriented paths, which end with the group of "relationship development (D)", indicating that these groups ultimately influence the coopetition strategies by promoting the development of good relationship among the members of IJVs in HSR projects. This view is consistent with balancing the interrelationships between competition and cooperation that can bring sustained mutual benefits (Dyer et al., 2018; Luo, 2004). The other is coopetitioncapability oriented paths, showing that these paths eventually influence the coopetition strategies by strengthening "firm capability (B)", which accounting for the view that coopetition capability is a distinctive organizational capability of interacting and sharing resources/skills with other firms for creating sustainable competitive advantage (Luo, 2005; Zhang et al., 2020a). Based on the two kinds

Table 1. Determinants for the coopetition strategies of IJVs in the HSR projects

\begin{tabular}{|c|c|c|c|c|c|c|c|c|c|c|c|c|c|c|c|c|c|}
\hline Groups & Factors & Level & 1 & 2 & 3 & 4 & 5 & 6 & 7 & 8 & 9 & 10 & 11 & 12 & 13 & 14 & 15 \\
\hline \multirow[t]{3}{*}{$\begin{array}{l}\text { A: macro } \\
\text { factors }\end{array}$} & $\begin{array}{l}\text { F1: inter-state relations of IJVs } \\
\text { members }\end{array}$ & Macro & & & & & & & & & & & & & & $\sqrt{ }$ & $\sqrt{ }$ \\
\hline & $\begin{array}{l}\text { F2: domestic support for } \\
\text { HSR contractors to enter the } \\
\text { international market }\end{array}$ & Macro & & & & & & & & & & & & & & $\sqrt{ }$ & $\sqrt{ }$ \\
\hline & $\begin{array}{l}\text { F3: industry international } \\
\text { reputation }\end{array}$ & Macro & & & $\sqrt{ }$ & & & & & & & & & & & & \\
\hline \multirow{3}{*}{$\begin{array}{l}\text { B: firm } \\
\text { capability }\end{array}$} & F4: financial capability & Firm & & & $\sqrt{ }$ & & & $\sqrt{ }$ & $\sqrt{ }$ & & $\sqrt{ }$ & & & & $\sqrt{ }$ & & $\sqrt{ }$ \\
\hline & F5: technical level & Firm & & & $\sqrt{ }$ & & & $\sqrt{ }$ & $\sqrt{ }$ & & $\sqrt{ }$ & & $\sqrt{ }$ & & $\sqrt{ }$ & & $\sqrt{ }$ \\
\hline & F6: corporate reputation & Firm & & & $\sqrt{ }$ & & & & & & & & $\sqrt{ }$ & & $\sqrt{ }$ & & \\
\hline \multirow{3}{*}{$\begin{array}{l}\text { C: management } \\
\text { leadership }\end{array}$} & F7: support from senior managers & Firm & $\sqrt{ }$ & & & $\sqrt{ }$ & $\sqrt{ }$ & $\sqrt{ }$ & & & & $\sqrt{ }$ & & $\sqrt{ }$ & & & \\
\hline & $\begin{array}{l}\text { F8: allocation of enterprise } \\
\text { resources }\end{array}$ & Firm & $\sqrt{ }$ & $\sqrt{ }$ & & $\sqrt{ }$ & $\sqrt{ }$ & $\sqrt{ }$ & $\sqrt{ }$ & & & $\sqrt{ }$ & & & & & $\sqrt{ }$ \\
\hline & $\begin{array}{l}\text { F9: inter-leadership relationship of } \\
\text { IJVs members }\end{array}$ & Firm & & $\sqrt{ }$ & & & & & $\sqrt{ }$ & & & & & & & & \\
\hline \multirow{6}{*}{$\begin{array}{l}\text { D: relationship } \\
\text { development }\end{array}$} & F10: inter-organizational trust & Firm & & $\sqrt{ }$ & & $\sqrt{ }$ & $\sqrt{ }$ & $\sqrt{ }$ & $\sqrt{ }$ & $\sqrt{ }$ & $\sqrt{ }$ & $\sqrt{ }$ & $\sqrt{ }$ & $\sqrt{ }$ & & & \\
\hline & F11: target conformance level & Firm & & & & $\sqrt{ }$ & & & & & $\sqrt{ }$ & $\sqrt{ }$ & & & & & \\
\hline & F12: cultural fit & Firm & $\sqrt{ }$ & & $\sqrt{ }$ & & & $\sqrt{ }$ & $\sqrt{ }$ & $\sqrt{ }$ & $\sqrt{ }$ & & & $\sqrt{ }$ & & $\sqrt{ }$ & \\
\hline & $\begin{array}{l}\text { F13: previous cooperation } \\
\text { experience }\end{array}$ & Firm & & & & & $\sqrt{ }$ & & $\sqrt{ }$ & $\sqrt{ }$ & $\sqrt{ }$ & & & & & $\sqrt{ }$ & \\
\hline & F14: communication & Firm & $\sqrt{ }$ & & & $\sqrt{ }$ & $\sqrt{ }$ & $\sqrt{ }$ & $\sqrt{ }$ & $\sqrt{ }$ & $\sqrt{ }$ & $\sqrt{ }$ & & $\sqrt{ }$ & & & \\
\hline & F15: long-term agreement & Firm & $\sqrt{ }$ & & & $\sqrt{ }$ & & $\sqrt{ }$ & & & & $\sqrt{ }$ & & & & & \\
\hline \multirow{3}{*}{$\begin{array}{l}\text { E: organization } \\
\text { structure }\end{array}$} & F16: employee participation & Firm & $\sqrt{ }$ & & & & & $\sqrt{ }$ & & & & & & & & & \\
\hline & $\begin{array}{l}\text { F17: setting up a professional } \\
\text { working department }\end{array}$ & Firm & & & & & $\sqrt{ }$ & $\sqrt{ }$ & & & & & & & & & \\
\hline & F18: organizational inspiration & Firm & $\sqrt{ }$ & $\sqrt{ }$ & & & & & & & & & & & & & \\
\hline \multirow{4}{*}{$\begin{array}{l}\text { F: project } \\
\text { management } \\
\text { capability }\end{array}$} & F19: risk sharing mechanism & Project & $\sqrt{ }$ & & $\sqrt{ }$ & & & & $\sqrt{ }$ & & & & $\sqrt{ }$ & & & & \\
\hline & F20: conflict resolution capability & Project & $\sqrt{ }$ & & & $\sqrt{ }$ & $\sqrt{ }$ & & $\sqrt{ }$ & $\sqrt{ }$ & $\sqrt{ }$ & $\sqrt{ }$ & & & & & \\
\hline & F21: contract integrity & Project & & & & & & & $\sqrt{ }$ & $\sqrt{ }$ & & & & & & & \\
\hline & F22: learning climate & Project & & & & & $\sqrt{ }$ & & & & & & & & & & \\
\hline
\end{tabular}

Note: 1- Chin et al. (2008); 2 - Thomason et al. (2013); 3 - Niu et al. (2019); 4 - Cheng et al. (2000); 5 - Cheng and Li (2001); 6 - Black et al. (2000); 7 - Mohamed et al. (2004); 8 - Ozorhon et al. (2007); 9 - Ozorhon et al. (2008a); 10 - Chan et al. (2004); 11 - Hwang et al. (2017); 12 - Zhang et al. (2010); 13 - Shen et al. (2006); 14 - Tse et al. (1997); 15 - Isa et al. (2014). 


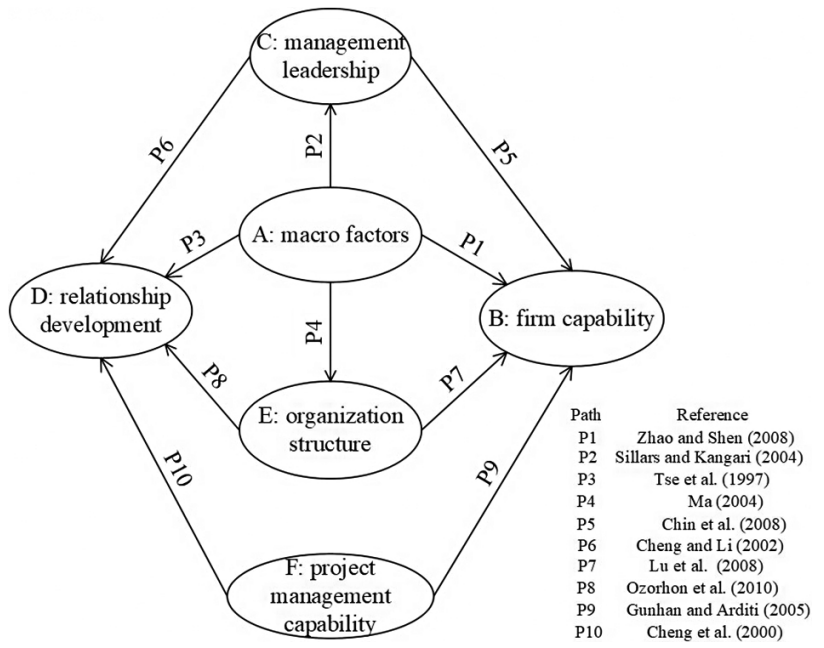

Figure 2. The hypothetical relationship among factor groups

of paths, the framework of the path model was proposed with literature supported in Figure 2. The method of proposing the hypothetical path model is comparable to some previous studies, such as Eybpoosh et al. (2011), Orozco et al. (2014), Liu et al. (2016, 2017), Zhao et al. (2018), Chang et al. $(2018,2019)$, and Niu et al. (2021).

\section{Research methods}

\subsection{Questionnaire survey}

A pilot survey of five experts with more than 15 years of experience in international HSR projects was performed to collect the experts' opinions towards the determinants for coopetition strategies of IJVs. Meanwhile, this study used the pilot study to test and validate the appropriateness and integrity of the determinants for coopetition strategies of IJVs in HSR projects. Through this process, all 22 determinants were considered important to the coopetition strategies of IJVs in HSR projects. What's more, some explanations of the factors were added to assure the accuracy of comprehension. For example, "F1, inter-state relations of IJVs members" refers to the relations among the home countries of IJVs members from different countries, including political relations, economic relations, diplomatic relations, cultural relations, military relations; "F3, Industry international reputation" refers to the approbation of domestic HSR related technical standards in the international market; "F6, corporate reputation" refers to the ability of corporate behavior to gain social recognition and thereby complete value creation; "F10, inter-organizational trust" refers to the relationship of mutual trust between members of the IJVs. "F22, learning climate" refers to a good atmosphere for employees from various contractors to learn from each other in the project department established by the joint venture.

After the pilot study, the structured questionnaire was distributed and collected that consists of two parts (see Appendix): (1) the information of the respondents (such as work experience, positions in a project or firm) and (2) respondents' attitudes towards the importance of the 22 determinants on a five-point Likert scale where $5=$ very important, $4=$ important, $3=$ medium, $2=$ small, and $1=$ not important.

From December 2019 to February 2020, a total of 210 questionnaires were distributed to the professionals via face-to-face interviews, email and an online chat tool. Among the 116 responses, three were ineffective because of the incomplete or inappropriate answers. The remaining 113 valid responses represent a $23.2 \%$ response rate, which was sufficient for the data analysis compared with the previous studies with the norm response rate of $20-30 \%$ in the research field of construction project (Akintoye, 2000; Deng et al., 2018). Additionally, as Hair et al. (1998) suggested that the valid questionnaires should be more than five times the variables (determinants), and in this study, the ratio exceeded 5:1. As indicated in Table 2, most of the respondents (67.26\%) had over ten years' work experience in the industry, and $53.98 \%$ of respondents have junior management or above positions (e. g. director or deputy director). Besides, all practitioners have the experience in international HSR projects, which further guaranteed the data quality.

Table 2. General information of the respondents

\begin{tabular}{|c|c|c|c|}
\hline Respondents & Categorization & $\begin{array}{l}\text { Number } \\
\text { of valid } \\
\text { responses }\end{array}$ & Percentage \\
\hline \multirow{4}{*}{$\begin{array}{l}\text { Position in } \\
\text { the project } \\
\text { or enterprise }\end{array}$} & Ordinary employee & 20 & 17.70 \\
\hline & Junior management & 32 & 28.32 \\
\hline & Middle management & 35 & 30.97 \\
\hline & Senior management & 26 & 23.01 \\
\hline \multirow{5}{*}{$\begin{array}{l}\text { Work } \\
\text { experience }\end{array}$} & $\leq 5$ years & 11 & 9.73 \\
\hline & $6-10$ years & 26 & 23.01 \\
\hline & $11-15$ years & 30 & 26.55 \\
\hline & $16-20$ years & 33 & 29.20 \\
\hline & $>20$ years & 13 & 11.51 \\
\hline \multirow{4}{*}{$\begin{array}{l}\text { Working } \\
\text { regional } \\
\text { segment }\end{array}$} & Asia & 54 & 47.79 \\
\hline & Africa & 44 & 38.94 \\
\hline & Europe & 10 & 8.85 \\
\hline & America & 5 & 4.42 \\
\hline \multirow{6}{*}{$\begin{array}{l}\text { Types of the } \\
\text { enterprises }\end{array}$} & Design enterprise & 20 & 17.70 \\
\hline & $\begin{array}{l}\text { Civil engineering } \\
\text { enterprise }\end{array}$ & 35 & 30.97 \\
\hline & $\begin{array}{l}\text { Manufacturing } \\
\text { enterprise }\end{array}$ & 27 & 23.89 \\
\hline & Operation enterprise & 18 & 15.93 \\
\hline & $\begin{array}{l}\text { Design and civil } \\
\text { engineering } \\
\text { enterprise }\end{array}$ & 10 & 8.85 \\
\hline & $\begin{array}{l}\text { Other (consulting } \\
\text { enterprise) }\end{array}$ & 3 & 2.66 \\
\hline
\end{tabular}




\subsection{Structural equation modeling (SEM)}

Structural equation modeling (SEM) is a multivariate statistical analysis method to test the relationship between constructs (Schreiber et al., 2006; Liu et al., 2016). SEM includes partial least-squares SEM (PLS-SEM) and covariance-based SEM (CB-SEM) due to the different algorithms (Fornell \& Bookstein, 1982). The sample size required for PLS-SEM is not very large, and the data distribution has no special requirements compared to CB-SEM (Sarstedt et al., 2011).

The coopetition strategies of IJVs in HSR projects are determined by the cross-level factors. So, the determinants are identified from different levels. However, the respondents are not cross-level. All of them are practitioners in HSR IJVs, who have the direct perception of how crosslevel factors determine the coopetition strategies. Therefore, the PLS-SEM is suitable for the data analysis in this study, and it is of a similar nature with the studies such as Orozco et al. (2014) and Zhai et al. (2020). Besides, owing to the advantages of PLS-SEM, it was applied to the path model analysis in this study using Smart PLS (version 3.3.2). Firstly, confirmatory factor analysis (CFA) was performed to verify the proposed measurement model which depicts the relationship between the 22 determinants and their corresponding groups. If the measurement model is reliable and well-fitted, the next step is to use the structural model for the path analysis to test the validity of the hypothetical relationship between the six groups.

In general, it is essential to evaluate the validity and reliability of the measurement model with the following principles: the factor loadings should be at least 0.6 (Hair et al., 1998); the composite reliability (CR) value of each variable should be at least 0.70 (Zuo et al., 2018); the average variance extracted (AVE) value of each factor category should be at least 0.5 (Fornell \& Bookstein, 1982); and the Cronbach's alpha coefficient should be at least 0.7 for internal consistency (Nunnally, 1978). In order to adequate discriminant validity, the square root of the AVE of each group should exceed the inter-group correlation (Davison \& Hinkley, 1997; Doloi et al., 2011). For the structural model, the hypothetical paths are tested by the two-tailed test through the bootstrapping technique, where the critical $t$-values are 1.65 (significance level $\mathrm{p}=$ $0.10), 1.96(\mathrm{p}=0.05)$, and $2.58(\mathrm{p}=0.01)($ Ong \& Musa, 2012; Awang et al., 2015).

\section{Results}

\subsection{Outer measurement model evaluation}

Table 3 shows that the CFA factor loadings range from 0.638 to $0.886(\geq 0.450)$, the CR of the six groups range from 0.751 to $0.864(\geq 0.700)$, and the AVE values range from 0.501 to $0.675(\geq 0.500)$. Additionally, the square root of AVE is higher than the correlation between any two groups (Table 4), which provided evidence that the measurement model is reliable and valid. Therefore, the model that clusters 22 determinants into four groups is reasonable.

\subsection{Inner structural model evaluation}

We tested the hypothesized causal relationship between the six groups through the structural model. As shown in Table 5, nine of the ten hypothesized relationships among the six groupings were significantly supported, while one was not. Clearly, P1, P2, P3, P4, P5, P6, P7, P8, P9 were significant at the $\mathrm{p}=0.01$ level, and $\mathrm{P} 10$ was significant at the $\mathrm{p}=0.10$, but P5 was not supported (Figure 3 ). The significance standards at these different levels were based on Ashraf (2004) and Zhao et al. (2018).

Table 3. Results of confirmatory factor analysis

\begin{tabular}{|c|c|c|c|c|}
\hline Factors & Factors loading & CR & AVE & alpha \\
\hline F1 & 0.812 & \multirow{3}{*}{0.895} & \multirow{3}{*}{0.740} & \multirow{3}{*}{0.824} \\
\hline F2 & 0.895 & & & \\
\hline F3 & 0.872 & & & \\
\hline $\mathrm{F} 4$ & 0.867 & \multirow{3}{*}{0.874} & \multirow{3}{*}{0.699} & \multirow{3}{*}{0.783} \\
\hline F5 & 0.772 & & & \\
\hline F6 & 0.866 & & & \\
\hline F7 & 0.887 & \multirow{3}{*}{0.885} & \multirow{3}{*}{0.721} & \multirow{3}{*}{0.80} \\
\hline F8 & 0.843 & & & \\
\hline F9 & 0.816 & & & \\
\hline F10 & 0.619 & \multirow{6}{*}{0.859} & \multirow{6}{*}{0.505} & \multirow{6}{*}{0.804} \\
\hline F11 & 0.707 & & & \\
\hline F12 & 0.747 & & & \\
\hline F13 & 0.658 & & & \\
\hline F14 & 0.767 & & & \\
\hline F15 & 0.754 & & & \\
\hline F16 & 0.857 & \multirow{3}{*}{0.847} & \multirow{3}{*}{0.652} & \multirow{3}{*}{0.732} \\
\hline F17 & 0.881 & & & \\
\hline F18 & 0.666 & & & \\
\hline F19 & 0.800 & \multirow{4}{*}{0.860} & \multirow{4}{*}{0.608} & \multirow{4}{*}{0.783} \\
\hline F20 & 0.666 & & & \\
\hline F21 & 0.783 & & & \\
\hline $\mathrm{F} 22$ & 0.857 & & & \\
\hline
\end{tabular}

Table 4. Discriminant validity of the six groups

\begin{tabular}{|c|c|c|c|c|c|c|}
\hline Groups & $\mathrm{A}$ & $\mathrm{B}$ & $\mathrm{C}$ & $\mathrm{D}$ & $\mathrm{E}$ & $\mathrm{F}$ \\
\hline $\mathrm{A}$ & 0.860 & & & & & \\
\hline B & 0.593 & 0.836 & & & & \\
\hline C & 0.327 & 0.274 & 0.849 & & & \\
\hline D & 0.597 & 0.730 & 0.426 & 0.711 & & \\
\hline E & 0.518 & 0.667 & 0.143 & 0.642 & 0.807 & \\
\hline F & 0.491 & 0.619 & 0.325 & 0.552 & 0.508 & 0.780 \\
\hline
\end{tabular}


Table 5. Path coefficients and significance

\begin{tabular}{|c|c|c|c|c|}
\hline Path & Coefficient & Std. & $t$-value & Interpretation \\
\hline P1 & $0.231^{* * *}$ & 0.070 & 3.306 & Supported \\
\hline P2 & $0.327^{* *}$ & 0.085 & 3.830 & Supported \\
\hline P3 & $0.230^{* * *}$ & 0.079 & 2.915 & Supported \\
\hline P4 & $0.518^{* *}$ & 0.073 & 0.112 & Supported supported \\
\hline P5 & 0.048 & 0.074 & 3.533 & Supported \\
\hline P6 & $0.242^{* * *}$ & 0.069 & 3.883 & Supported \\
\hline P7 & $0.393^{* * *}$ & 0.101 & 5.534 & Supported \\
\hline P8 & $0.412^{* * *}$ & 0.074 & 3.510 & Supported \\
\hline P9 & $0.291^{* * *}$ & 0.083 & 1.820 & Supported \\
\hline P10 & $0.150^{*}$ & 0.082 & & \\
\hline
\end{tabular}

Note: ${ }^{*}$ Path is significant at the $\mathrm{p}=0.10$ level; ${ }^{* * *}$ Path is significant at the $\mathrm{p}=0.01$ level.

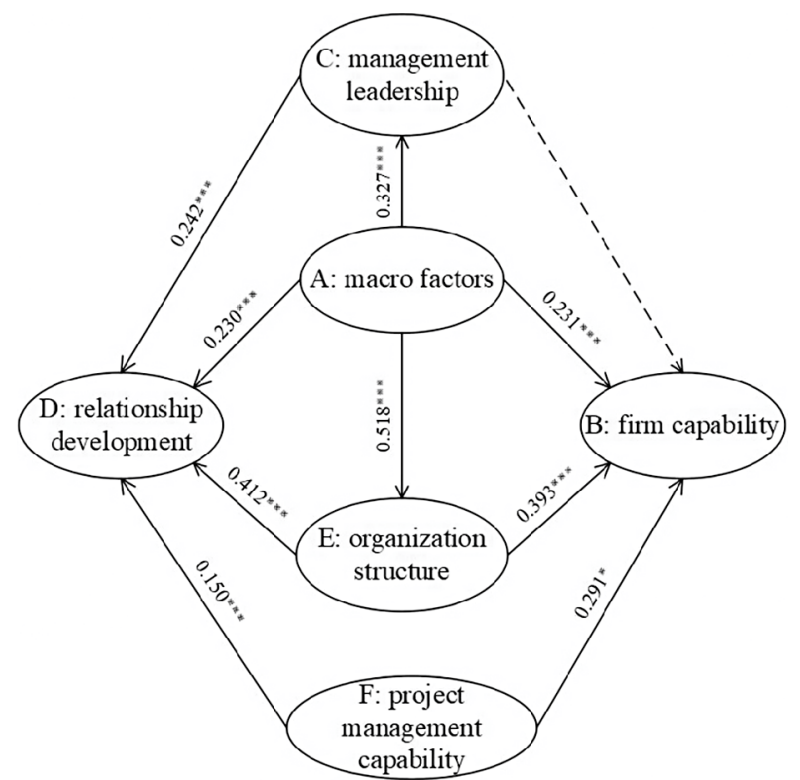

Notes: ${ }^{* * *}$ significance level $=1 \% ;{ }^{* *}$ significance level $=5 \%$; ${ }^{*}$ significance level $=10 \%$

$\longrightarrow$ Indicated hypothesis path supported

$--\rightarrow$ Indicated hypothesis path not supported

Figure 3. Paths model of determinants for coopetition strategies of IJVs in HSR projects

\section{Discussions and recommendations}

\subsection{Discussions}

\subsubsection{Coopetition-relationship oriented paths}

There are four cross-level paths (macro-level to the firmlevel, project-level to the firm-level): "Macro Factors" $\rightarrow$ "Management Leadership", "Macro Factors" $\rightarrow$ "Relationship Development", "Macro Factors" $\rightarrow$ "Organization Structure", and "Project Management Capability" $\rightarrow$ "Relationship Development". The first path indicated that in the face of macro-level support, managers may proactively look for new opportunities to create situations that are conducive to successful coopetition strategies for IJVs (Sillars \& Kangari, 2004). The second path uncovers that an important way for the members of IJVs to improve the relationship with each other. For example, good inter-state relations between the two countries can promote win-win cooperation between contractors from both countries. Likewise, as Tse et al. (1997) pointed out, a long and harmonious diplomatic history between the two countries, which is a macro factor, could deepen the understanding between the contractors from the two countries and thus promote a good relationship. For the third path, in the face of macro-level support, managers may proactively look for new opportunities to create situations that are conducive to success for IJVs (Sillars \& Kangari, 2004). The fourth path echoes the view of Cheng et al. (2000) about the relation of project management capability and relationship development.

For the Coopetition-relationship oriented paths, besides the four cross-level paths above, there are two paths within a firm-level: "Management Leadership" $\rightarrow$ "Relationship Development" and "Organization Structure" $\rightarrow$ "Relationship Development". The first path proposed that partnerships were easier to build and sustain when senior managers had the intent to work on building partnerships as Cheng and $\mathrm{Li}$ (2002) demonstrated in their research. For the other path, establishing a good IJVs structure can strengthen the relationship of commitment, cooperation, communication, and trust among partners in the operation of IJVs (Ozorhon et al., 2010).

\subsubsection{Coopetition-capability oriented paths}

There are two cross-level paths (macro-level to the firm level, project level to the firm level): "Macro Factors" $\rightarrow$ "Firm Capability" and "Project Management Capability" $\rightarrow$ "Firm Capability". First, if the strategic direction of contractors to explore international markets is in line with national development strategies, some policies at the macro level, such as financial support from home governments, can effectively help the development of firms and the improvement of their strength (Zhao \& Shen, 2008). In order to support the development of Chinese contractors in the overseas markets, the Ministry of Finance, the Export-Import Bank of China, and others have provided measures for strengthening financial security for Chinese 
international contractors, such as the China Export and Import Bank provided export credit support for overseas projects undertaken by Chinese contractors (Zhao \& Shen, 2008) so that such macro-policy support to enhance the capability of the firm. Second, the economic complexity, political complexity and cultural differences faced by international HSR projects make them more difficult to manage than domestic projects because they involve more risks and are more difficult to predict (Chang et al., 2019), so improving project management capability is a necessary way to ensure the success of coopetition strategies. The IJVs bring together the members of the IJVs in the form of the project department. Therefore, improving project management capability can enhance the capability of the firm.

For the Coopetition-capability oriented paths, besides the two cross-level paths above, there is one path within a firm-level: "Organization Structure" $\rightarrow$ "Firm Capability". The organization structure was deemed important for enhancing the competitiveness of a construction organization (Lu et al., 2008). Therefore, through the innovation of organization structure, we can improve the capability of contractors to ensure a competitive advantage.

\subsection{Recommendations}

According to these identified determinants and verified interactive paths, the members of the IJVs can find various ways to enhance their coopetition capability or improve the coopetition relationship among members and thus optimize their coopetition strategies (Figure 4). In the preproject phase, there are two recommendations based on the paths of "Macro Factors (A)" $\rightarrow$ "Firm Capability(B)", "Macro Factors (A)" $\rightarrow$ "Relationship Development (D)", and "Management Leadership (C)" $\rightarrow$ "Relationship Development (D)". Also, in the project implementation phase, the two recommendations were proposed based on the paths of "Project Management Capability (F)" $\rightarrow$ "Firm
Capability (B)", "Project Management Capability (F)" $\rightarrow$ "Relationship Development (D)", "Organization Structure $(\mathrm{E})$ " $\rightarrow$ "Relationship Development (D)", and "Organization Structure (E)" $\rightarrow$ "Firm Capability (B)". What's more, given the critical role of "long-term agreement (F15)" and "communication (F14)" in the group of "Relationship Development (D)", the members of IJVs in HSR projects could take two recommendations in the post-project phase. In order to refine the six recommendations in Figure 4, the specific and detailed measures for each recommendation are presented at the macro, firm, and project levels for three different project phases (pre-project phase, project implementation phase, and post-project phases) (Figure 5).

In the pre-project phase, the recommendations for the members of IJVs are from the macro and firm level.

(1) From the macro level, because the government has high expectations for HSR, it is necessary to obtain

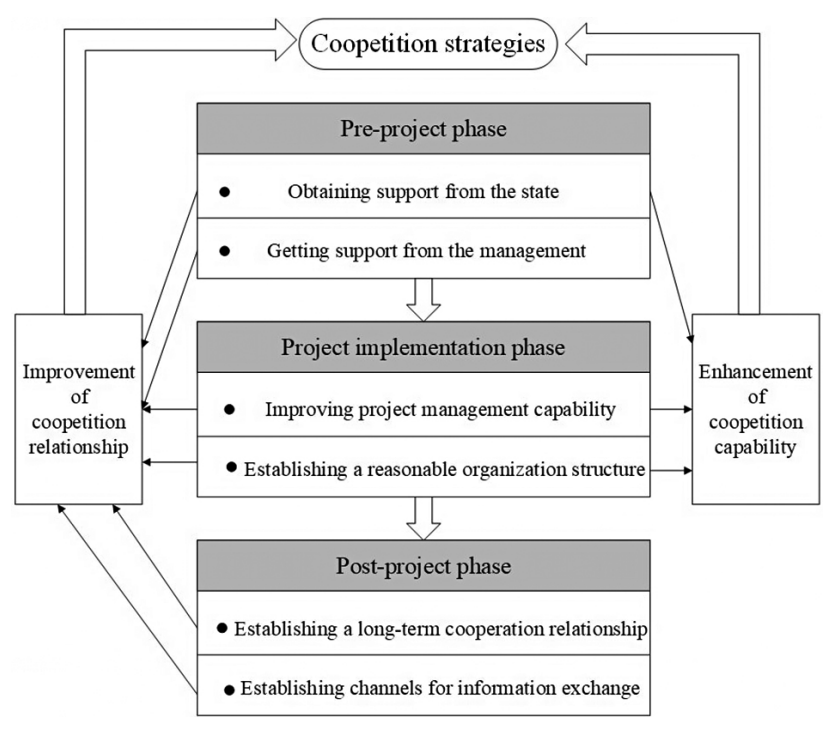

Figure 4. Application of the path model

\begin{tabular}{|c|c|c|}
\hline Pre-project phase & Project implementation phase & Post-project phase \\
\hline - Obtaining support from the state & $\begin{array}{l}\text { - Improving project management } \\
\text { capability }\end{array}$ & $\begin{array}{l}\text { - } \\
\text { Establishing a long-term } \\
\text { cooperation relationship }\end{array}$ \\
\hline $\begin{array}{l}\text { (i) Actively obtaining support from policy-funded } \\
\text { financial institutions (BRICS Development Bank, Silk } \\
\text { Road Fund, Asian Infrastructure Investment Bank) } \\
\text { (ii) Making full use of the memorandum of multilateral } \\
\text { cooperation signed by national leaders through the } \\
\text { prime minister's visit }\end{array}$ & $\begin{array}{l}\text { (i) Establishing a comprehensive life cycle risk } \\
\text { management mechanism for risk identification, } \\
\text { assessment, response, tracking and control } \\
\text { (ii) Improving the awareness of the contract and } \\
\text { paying attention to the research and negotiation of } \\
\text { key terms }\end{array}$ & $\begin{array}{l}\text { (i) Conducting forums and exhibitions to deepen } \\
\text { mutual understanding and create opportunities for } \\
\text { cooperation }\end{array}$ \\
\hline - Getting support from the managemnet & $\begin{array}{c}\text { - } \begin{array}{c}\text { Establishing a reasonable } \\
\text { organization structure }\end{array} \\
\end{array}$ & $\begin{array}{l}\text { - Establishing channels for } \\
\text { information exchange }\end{array}$ \\
\hline $\begin{array}{l}\text { (i) Organizing technical teams to conduct on-site } \\
\text { research }\end{array}$ & $\begin{array}{l}\text { (i) Setting up a special working group to connect the } \\
\text { problems that arise during the implementation of the } \\
\text { project } \\
\text { (ii) Cultivating and establishing an international team } \\
\text { of professions }\end{array}$ & $\begin{array}{l}\text { (i) Establishing an information exchange mechanism } \\
\text { with the international tax and exchange rate } \\
\text { information, etc. } \\
\text { (ii) Actively participating in the development of } \\
\text { international standards for HSR }\end{array}$ \\
\hline Macro and firm level & Firm and project level & Firm level \\
\hline
\end{tabular}

Figure 5. Measures at different project phases 
support from the national macro level for bidding for international HSR projects (Andrić et al., 2019). Many policy-funded financial institutions and mechanisms, such as the BRICS Development Bank, the Silk Road Fund, the Asia Infrastructure Investment Bank (AIIB), etc., have carried out related activities to promote multi-country cooperation (Sillars \& Kangari, 2004; Zhao \& Shen, 2008). It is time for the HSR contractors to obtain the support of these policy-funded financial institutions and mechanisms. For example, the "business-to-business" approach adopted by the JakartaBandung HSR project means that the Indonesian government does not provide any government funding or official loan guarantee. Yet, to overcome the enormous challenge of financial pressure in this project, China Development Bank provided loans that accounted for $75 \%$ of the total cost, with a $2 \%$ interest rate to this project, helping Chinese contractors win bids for this HSR project. Therefore, it is worth noting that the crucial measure for IJVs in HSR projects is to obtain support from policy-funded financial institutions.

(2) Also, at the macro level, the members of IJVs should make full use of the memorandum of multilateral cooperation signed by national leaders, which is a sign of friendly diplomatic relations between the two countries, to promote the implementation of relevant international HSR projects. For instance, in order to promote the Chinese HSR "going abroad", the government has carried out plenty of diplomatic activities, such as the national leader's visit and bilateral cooperation, which has an important impact on the coopetition relationship of the members of IJVs and facilitate the implementation of the coopetition strategies. For example, in the pre-project phase of the JakartaBandung HSR project, the Chinese government and the Indonesian government signed a Memorandum of Understanding to prepare the policy support for the IJVs (Wang et al., 2015). Additionally, the multilateral cooperation mode, such as the Group of 20, Asia-Pacific Economic Cooperation, the Shanghai Cooperation Organization, the Forum on China-Africa Cooperation, and the World Economic Forum have laid a solid foundation for Chinese HSR contractors to explore international markets and promote the Belt and Road Initiative.

(3) At the firm level, the support from the management of firms can lay a solid foundation for winning the bidding, such as organizing technical teams to conduct on-site research and project feasibility studies (Cheng et al., 2000; Tetteh et al., 2020). For example, for the sake of obtaining the Jakarta-Bandung HSR project, the members of IJVs have been tracking the project for many years, and have equipped the project with human and financial resources, such as in-depth market investigation, preliminary feasibility study, and real-time market demand monitoring. In the end, the IJVs won the project, extraordinarily benefiting from the effective allocation of resources by the members of
IJVs in HSR projects. On the contrary, due to the lack of comprehensive and in-depth research in the preproject phase, the members of the IJVs did not have enough understanding of the political and social situation in Mexico, which eventually led to the abeyance of the Mexico City-Queretaro HSR project.

During the HSR project implementation phase, it is essential to propose recommendations at the firm and project levels.

(1) From the project level, given that project management capability has a significant impact on the firm capability and relationship development of the members of IJVs, it is important to pay attention to the improvement of project management capability throughout the project implementation process. For instance, the members of IJVs should establish a comprehensive life cycle risk management mechanism for risk identification, assessment, response, tracking, and control (Zhao et al., 2014). The political risk of the international HSR project is one of the key issues to pay attention to, from the selection of the target project, the project preparation stage, the project implementation stage to the risk-taking stage, should be formulated accordingly (Chang et al., 2018). For example, the host country of the Jakarta-Bandung HSR project faced extreme religious problems. Personal freedom and security of five Chinese employees in the IJVs (PT. Kereta Cepat Indonesia-China, KCIC) were threatened due to political risks related to the Islamic extremist group. Political risk has always been an important dilemma for international HSR projects, so in the process of project implementation, practitioners should fully understand the local political, economic, cultural, and other conditions, to minimize conflict and risk.

(2) Additionally, at the project-level, the integrity of the contract signed between the members of IJVs, such as the provisions on the approval of the contract, the documentation of the contract, the change of contract, etc., will directly affect the implementation of the projects. Thus, the members of IJVs should improve the awareness of the contract and pay attention to the research and negotiation of key terms (Mohamed et al., 2004). As Shen et al. (2001) confirmed that incomplete contract terms with partners had a negative impact on IJVs. Thus, the integrity of the contract would cause reliable protection, thereby facilitating the implementation of the coopetition strategies of IJVs in HSR projects.

(3) From the perspective of the firm level, the firms forming the IJVs should establish a non-flexible organization structure to efficiently connect to IJVs, through setting up a professional working department to meet and adapt the target requirements to the problems during the implementation of the projects (Cheng et al., 2000; Tetteh et al., 2020). Contrary, unstructured management framework would impede IJVs success (McIntosh \& McCabe, 2003; Lu et al., 2020). 
(4) Furthermore, at the firm level, an international team of professional personnel with rich and high-quality experience could have a positive impact on the implementation of the coopetition strategy (Zhang et al., 2019). For example, in the Mecca-Medina HSR project, from the project manager to the foreman can communicate with the local people in English and Arabic. To improve employees' enthusiasm, the IJVs can establish a systematic salaries and benefits system and explore various incentive methods. Moreover, building a multi-level and systematic training system, such as thematic training, enhances the knowledge literacy of employees (Tetteh et al., 2020).

It is sensible for the members of IJVs to take the following measures from the firm level after accomplishing the HSR projects.

(1) In the phase of post-project, the members of IJVs should establish a long-term connection and cooperation mechanism with each other, such as international forums, HSR technology exhibitions, etc., to deepen understanding and create opportunities for cooperation (Zhang et al., 2020b). For instance, Chinese contractors holding a China HSR technology exhibition in Shanghai increased the possibility of winning the bid for the Jakarta-Bandung HSR project (Zhang et al., 2020b).

(2) HSR contractors should pay attention to the latest information relating to the international HSR market (Chan et al., 2020). For instance, establishing an information exchange mechanism provides HSR contractors with the up-to-date information, containing international tax and exchange rate information, etc. (Gale \& Luo, 2004; Zhao \& Shen, 2008; Lu et al., 2020).

(3) HSR contractors should actively participate in the development of international railway standards to improve the recognition of Chinese standards in the international HSR market. So far, the UIC members have included 10 Chinese members, of whom three are active members, one associate member, and six affiliated members, which shows that the relevant railway institutions in China work closely with UIC. Besides, China's HSR firms should strengthen communication and contact with other international railway organizations, such as the International Organization for Standardization (ISO), the International Electron Commission (IEC), and so on, to compare and analyze the differences with international advanced standards and thus enhance the compatibility of Chinese railway technical standards (Zhou et al., 2019; Zhang et al., 2020a).

\section{Conclusions}

In this study, based on the literature review and pilot study, a total of 22 determinants for the coopetition strategies of IJVs in HSR projects involving macro, firm, and project levels were identified and divided into six groups: (A) macro factors, (B) firm capability, (C) management leadership, (D) relationship development, (E) organization structure, and (F) project management capability. Also, the path model of 10 hypothetical paths was proposed. Then the questionnaire survey was conducted to obtain the data. By analysis of the survey data, the categorizations of 22 determinants and nine of the ten hypothetical paths were statistically significant by the PLS-SEM method. Furthermore, these significant paths were grouped into two categories (the coopetition-relationship oriented paths, and the coopetition-capability oriented paths). Based on the results of CFA and path analysis, we discussed the recommendations that contribute to the determinants of coopetition strategies in three different phases.

The theoretical contribution could be presented in two aspects:

(1) It constructed a conceptual framework of the determinants for coopetition strategies of IJVs in HSR projects, which extends the knowledge system of coopetition.

(2) Different from the previous studies that concentrated on a single level of determinants, this study focuses on the cross-level determinants for coopetition strategies of the IJVs (including macro, firm, and project level), which provides a direction for future research.

The practical implications derived from this study are as follows:

(1) The findings of this study help to strengthen the understanding of both competition and cooperation among the members of IJVs in HSR projects, which emphasizes that competition and cooperation are not separate and contradictory but can keep an appropriate balance between them.

(2) This study could guide the members of IJVs in HSR projects not only to pay attention to the improvement of coopetition relationship but also to enhance the coopetition capability. Both coopetition relationship and coopetition capability would impact the superior performance of the members of IJVs in HSR projects.

(3) The establishment of a path model for 22 determinants can reveal the relationships among the determinants, and provide the members of IJVs in HSR projects with direct guidance to develop improvement plans for coopetition strategies in cases of no sufficient resources to handle all determinants at the same time. The primary limitation of this study was that majority of respondents were from HSR contractors in Asia. Yet this was indeed acceptable as all respondents had rich experience in international HSR and had a deep understanding of IJVs. However, this study contributes to the coopetition strategies management in the model of IJVs in HSR projects. Finally, it is recommended that future research would be conducted to exam the influence of these determinants on performance to increase practical validity.

\section{Acknowledgements}

This study was supported by the National Natural Science Foundation of China (Grant Nos. 72071133, 71771052, and 71972018); the Research Project on Humanities and 
Social Sciences of Hebei Higher Education Institutions (Top Young Scholar Project) (Grant No. BJ2019079); the Fundamental Research Funds for the Hebei Universities (Grant No. SQK202002); the Natural Science Foundation of Hebei (Grant No. G2019210226); Innovation Funding Project for Graduate Students of Shijiazhuang Tiedao University [YC2020043]; and Scientific Research Planning Project of China State Railway Group [2020F026].

\section{References}

Afuah, A. (2000). How much do your coopetitors' capabilities matter in the face of technological change?. Strategic Management Journal, 21(3), 387-404.

https://doi.org/10.1002/(sici)1097-0266(200003)21:3\%3C397 ::aid-smj88\%3E3.0.co;2-1

Akintoye, A. (2000). Analysis of factors influencing project cost estimating practice. Construction Management and Economics, 18(1), 77-89. https://doi.org/10.1080/014461900370979

Andrić, J. M., Wang, J., \& Zhong, R. (2019). Identifying the critical risks in railway projects based on fuzzy and sensitivity analysis: A case study of belt and road projects. Sustainability, 11(5), 1302. https://doi.org/10.3390/su11051302

Antolín-López, R., Delgado-Ceballos, J., \& Montiel, I. (2016). Deconstructing corporate sustainability: a comparison of different stakeholder metrics. Journal of Cleaner Production, 136, 5-17. https://doi.org/10.1016/j.jclepro.2016.01.111

Ashraf, M (2004). A critical look at the use of group projects as a pedagogical tool. Journal of Education for Business, 79(4), 213-216. https://doi.org/10.3200/joeb.79.4.213-216

Awang, Z., Afthanorhan, W. M. A. W., \& Asri, M. A. M. (2015). Parametric and non-parametric approach in structural equation modeling (SEM): The application of bootstrapping. Modern Applied Science, 9(9), 58-67.

https://doi.org/10.5539/mas.v9n9p58

Bengtsson, M., \& Kock, S. (2000). Coopetition' in business networks-to cooperate and compete simultaneously. Industrial Marketing Management, 29, 411-426.

https://doi.org/10.1016/S0019-8501(99)00067-X

Bengtsson, M., \& Raza-Ullah, T (2016). A systematic review of research on coopetition: toward a multilevel understanding. Industrial Marketing Management, 57, 23-39. https://doi.org/10.1016/j.indmarman.2016.05.003

Bilotkach, V., \& Hüschelrath, K. (2019). Balancing competition and cooperation: evidence from transatlantic airline markets. Transportation Research Part A: Policy and Practice, 120, 1-16. https://doi.org/10.2139/ssrn.2661477

Black, C., Akintoye, A., \& Fitzgerald, E. (2000). An analysis of success factors and benefits of partnering in construction. International Journal of Project Management, 18(6), 423-434. https://doi.org/10.1016/s0263-7863(99)00046-0

Brandenburger, A., \& Nalebuff, B. J. (1996). Coopetition. Free Press.

Chan, A. P. C., Chan, D. W. M., Chiang, Y. H., Tang, B. S., Chan, E. H. W., \& Ho, K. S. K. (2004). Exploring critical success factors for partnering in construction projects. Journal of Construction Engineering and Management, 130(2), 188-198. https://doi.org/10.1061/(ASCE)0733-9364(2004)130:2(188)

Chan, E. H., \& Suen, H. C. (2005). Disputes and dispute resolution systems in Sino-foreign joint venture construction projects in China. Journal of Professional Issues in Engineering Education and Practice, 31(2), 141-148.

https://doi.org/10.1061/(ASCE)1052-3928(2005)131:2(141)
Chan, A. P. C., Tetteh, M. O., \& Nani, G. (2020). Drivers for international construction joint ventures adoption: a systematic literature review. International Journal of Construction Management. https://doi.org/10.1080/15623599.2020.1850203

Chang, T., Deng, X., Hwang, B.-G., \& Zhao, X. (2018). Political risk paths in international construction projects: Case study from Chinese construction enterprises. Advances in Civil Engineering, Article ID 6939828.

https://doi.org/10.1155/2018/6939828

Chang, T., Deng, X., \& Hwang, B.-G. (2019). Investigating political risk paths in international high-speed railway projects: The case of Chinese international contractors. Sustainability, 11(15), 4157. https://doi.org/10.3390/su11154157

Cheng, E. W. L., \& Li, H. (2001). Development of a conceptual model of construction partnering. Engineering, Construction and Architectural Management, 8(4), 292-303.

https://doi.org/10.1108/eb021190

Cheng, E. W. L., \& Li, H. (2002). Construction partnering process and associated critical success factors: Quantitative investigation. Journal of Management in Engineering, 18(4), 194-202. https://doi.org/10.1061/(ASCE)0742-597X(2002)18:4(194)

Cheng, E. W. L., Li, H., \& Love, P. E. D. (2000). Establishment of critical success factors for construction partnering. Journal of Management in Engineering, 16(2), 84-92.

https://doi.org/10.1061/(ASCE)0742-597X(2000)16:2(84)

Chin, K. S., Chan, B. L., \& Lam, P. K. (2008). Identifying and prioritizing critical success factors for coopetition strategy. Industrial Management and Data System, 108(3-4), 437-454. https://doi.org/10.1108/eb021190

Chou, J.-S., Tserng, H. P., Lin, C., \& Yeh, C.-P. (2012). Critical factors and risk allocation for PPP policy: comparison between HSR and general infrastructure projects. Transport Policy, 22, 36-48. https://doi.org/10.1016/j.tranpol.2012.05.009

Cozzolino, A., \& Rothaerme, F. T. (2018). Discontinuities, competition, and cooperation: Coopetitive dynamics between incumbents and entrants. Strategic Management Journal, 39(2), 3053-3058. https://doi.org/10.1002/smj.2776

Crick, J. M. (2019). The dark side of coopetition: when collaborating with competitors is harmful for company performance. Journal of Business \& Industrial Marketing, 35(2), 318-337. https://doi.org/10.1108/jbim-01-2019-0057

Crick, J. M., \& Crick, D. (2020). The yin and yang nature of coopetition activities: non-linear effects and the moderating role of competitive intensity for internationalised firms. International Marketing Review.

https://doi.org/10.1108/imr-01-2019-0018

Davison, A. C., \& Hinkley, D. V. (1997). Bootstrap methods and their application. Cambridge University Press.

https://doi.org/10.1017/CBO9780511802843

Deng, X., Low, S. P., Zhao, X., \& Chang, T. (2018). Identifying micro variables contributing to political risks in international construction projects. Engineering, Construction and Architectural Management, 25, 317-333.

https://doi.org/10.1108/ecam-02-2017-0042

Doloi, H., Iyer, K. C., \& Sawhney, A. (2011). Structural equation model for assessing impacts of contractor's performance on project success. International Journal of Project Management, 29(6), 687-695.

https://doi.org/10.1016/j.ijproman.2010.05.007

Dorn, S., Schweiger, B., \& Albers, S. (2016). Levels, phases and themes of coopetition: A systematic literature review and research agenda. European Management Journal, 34(5), 484500. https://doi.org/10.1016/j.emj.2016.02.009 
Dyer, D. H., Singh, H., \& Hesterly, W. S. (2018). The relational view revisited: A dynamic perspective on value creation and value capture. Strategic Management Journal, 39(12), 31403162. https://doi.org/10.1002/smj.2785

Eybpoosh, M., Dikmen, I., \& Birgonul, M. T. (2011). Identification of risk paths in international construction projects using structural equation modeling. Journal of Construction Engineering and Management, 137(12), 116-1175.

https://doi.org/10.1061/(ASCE)CO.1943-7862.0000382

Fornell, C., \& Bookstein, F. L. (1982). Two structural equation models: LISREL and PLS applied to consumer exit-voice theory. Journal of Marketing Research, 19(4), 440-452. https://doi.org/10.1177/002224378201900406

Gale, A., \& Luo, J. (2004). Factors affecting construction joint ventures in China. International Journal of Project Management, 22(1), 33-42. https://doi.org/10.1016/s0263-7863(03)00012-7

Ganesan, S., \& Kelsey, J. (2006). Technology transfer: International collaboration in Sri Lanka. Construction Management and Economics, 24(7), 743-754.

https://doi.org/10.1080/01446190600704703

Girmscheid, G., \& Brockmann, C. (2010). Inter- and intra-organizational trust in international construction joint ventures. Journal of Construction Engineering and Management, 136(3), 353-360.

https://doi.org/10.1061/(ASCE)CO.1943-7862.0000142

Gnyawali, D. R., \& Madhavan, R. (2001). Cooperative network competitive dynamics: a structural embeddedness perspective. Academy of Management Review, 26(3), 431-445. https://doi.org/10.5465/amr.2001.4845820

Hair, J. F., Anderson, R. E., Tatham, R. L., \& Black, W. C. (1998). Multi-variate data analysis (5th ed.). Prentice Hall.

Hannah, D. P., \& Eisenhardt, K. D. (2018). How firms navigate cooperation and competition in nascent ecosystems. Strategic Management Journal, 39(13), 3163-3192.

https://doi.org/10.2139/ssrn.2808034

Hong, Y., \& Chan, D. W. M. (2014). Research trend of joint ventures in construction: A two-decade taxonomic review. Journal of Facilities Management, 12(2), 118-141. https://doi.org/10.1108/JFM-04-2013-0022

Hwang, B. G., Zhao, X., \& Ng, S. Y. (2013). Identifying the critical factors affecting schedule performance of public housing projects. Habitat International, 38, 214-221.

https://doi.org/10.1016/j.habitatint.2012.06.008

Hwang, B. G., Zhao, X., \& Yu, G. S. (2016). Risk identification and allocation in underground rail construction joint ventures: Contractors' perspective. Journal of Civil Engineering and Management, 22(6), 758-767.

https://doi.org/10.3846/13923730.2014.914095

Hwang, B. G., Zhao, X., \& Chin, E. W. Y. (2017). International construction joint ventures between Singapore and developing countries: Risk assessment and allocation preferences. Engineering, Construction and Architectural Management, 24(2), 209-228. https://doi.org/10.1108/ECAM-03-2015-0035

Isa, C., Saman, H., \& Preece, C. (2014). Entry location and entry timing (ELET) decision model for international construction firms. Construction Economics and Building, 14(3), 34-57. https://doi.org/10.5130/AJCEB.v14i3.4156

Ivaldi, M., \& Pouyet, J. (2018). Eliciting the regulation of an economic system: The case of the French rail industry. Transport Policy, 62, 21-30.

https://doi.org/10.1016/j.tranpol.2017.04.003

Levy, M., Loebbecke, C., \& Powell, P. (2003). SMEs, co-opetition and knowledge sharing: The role of information systems. European Journal of Information Systems, 12(1), 3-17. https://doi.org/10.1057/palgrave.ejis.3000439
Li, B., Akintoye, A., Edwards, P. J., \& Hardcastle, C. (2005). Critical success factors for PPP/PFI projects in the UK construction industry. Construction Management and Economics, 23(5), 459-471. https://doi.org/10.1080/01446190500041537

Liu, J., Zhao, X., \& Li, Y. (2016). Exploring the factors inducing contractors' unethical behavior: case of China. Journal of Professional Issues in Engineering Education and Practice, 143(3), 0000316.

https://doi.org/10.1061/(ASCE)EI.1943-5541.0000316

Liu, J., Xie, Q., Xia, B., \& Bridge, A. J. (2017). Impact of design risk on the performance of design-build projects. Journal of Construction Engineering and Management, 143(6), 04017010. https://doi.org/10.1061/(ASCE)CO.1943-7862.0001299

Luo, Y. (2004). A coopetition perspective of MNC-host government relations. Journal of International Management, 10(4), 431-451. https://doi.org/10.1016/j.intman.2004.08.004

Luo, Y. (2005). Toward coopetition within a multinational enterprise: a perspective from foreign subsidiaries. Journal of World Business, 40(1), 71-90.

https://doi.org/10.1016/j.jwb.2004.10.006

Luo, Y. (2007). A coopetition perspective of global competition. Journal of World Business, 42(2), 129-144. https://doi.org/10.1016/j.jwb.2006.08.007

Lu, W.-S., Shen, L.-Y., \& Yam, M. C. (2008). Critical success factors for competitiveness of contractors: China study. Journal of Construction Engineering and Management, 134(12), 972-982. https://doi.org/10.1061/(ASCE)0733-9364(2008)134:12(972)

Lu, C., Yu, Z., Wang, X., \& Hong, Y. (2020). Empirical study on the obstacles to the success of joint ventures in construction projects. Advances in Civil Engineering, Article ID 1748198. https://doi.org/10.1155/2020/1748198

Maemura, Y., Kim, E., \& Ozawa, K. (2018). Root causes of recurring contractual conflicts in international construction projects: Five case studies from Vietnam. Journal of Construction Engineering and Management, 144(8), 05018008.

https://doi.org/10.1061/(ASCE)CO.1943-7862.0001523

Mariani, M. M. (2007). Coopetition as an emergent strategy: Empirical evidence from an Italian Consortium of Opera Houses. International Studies of Management \& Organization, 37(2), 97-126. https://doi.org/10.2753/imo0020-8825370205

McIntosh, M., \& McCabe, B. (2003). Risk and benefits associated with international construction-consulting joint ventures in the English-speaking Caribbean. Canadian Journal of Civil Engineering, 30(6), 1143-1152. https://doi.org/10.1139/103-063

Mohamed, M., Stankosky, M., \& Murray, A. (2004). Applying knowledge management principles to enhance cross-functional team performance. Journal of Knowledge Management, 8(3), 127-142. https://doi.org/10.1108/13673270410541097

Niu, Y., Deng, X., Zhang, L., \& Duan, X. (2019). Understanding critical variables contributing to competitive advantages of international high-speed railway contractors. Journal of Civil Engineering and Management, 25(2), 184-202.

https://doi.org/10.3846/jcem.2019.8427

Niu, Y., Deng, X., Zhao, X., \& Zhang, N. (2020). Hexagonal diamond model for international competitive advantages of high-speed railway industry. Journal of Management in Engineering, 36(2), 04020001.

https://doi.org/10.1061/(ASCE)ME.1943-5479.0000746

Niu, Y., Zhao, X., Wang, Y., \& Deng, X. (2021). Locomotive model for international competitive advantages paths of highspeed railway contractors. Journal of Infrastructure Systems, 27(2), 04021002.

https://doi.org/10.1061/(ASCE)IS.1943-555X.0000600 
Nunnally, J. C. (1978). Psychometric theory (2nd ed.). McGrawHill.

Ong, T. F., \& Musa, G. (2012). Examining the influences of experience, personality and attitude on SCUBA divers' underwater behavior: a structural equation model. Tourism Management, 33(6), 1521-1534.

https://doi.org/10.1016/j.tourman.2012.02.007

Orozco, F. A., Serpell, A. F., Molenaar, K. R., \& Forcael, E (2014). Modeling competitiveness factors and indexes for construction companies: Findings of Chile. Journal of Construction Engineering and Management, 140 (4), B4013002. https://doi.org/10.1061/(ASCE)CO.1943-7862.0000462.

Ozorhon, B., Dikmen, I., \& Birgonul, M. T. (2007). Using analytic network process to predict the performance of international construction joint ventures. Journal of Management in Engineering, 23(3), 156-163. https://doi.org/10.1061/(ASCE)0742-597X(2007)23:3(156)

Ozorhon, B., Arditi, D., Dikmen, I., \& Birgonul, M. T. (2008a). Effect of partner fit in international construction joint ventures. Journal of Management in Engineering, 24(1), 12-20. https://doi.org/10.1061/(ASCE)0742-597X(2008)24:1(12)

Ozorhon, B., Arditi, D., Dikmen, I., \& Birgonul, M. T. (2008b). Implications of culture in the performance of international construction joint Ventures. Journal of Construction Engineering and Management, 134(5), 361-370. https://doi.org/10.1201/9781482266665-105

Ozorhon, B., Arditi, D., Dikmen, I., \& Birgonul, M. T. (2010). Performance of international joint ventures in construction. Journal of Management in Engineering, 26(4), 209-222. https://doi.org/10.1061/(ASCE)ME.1943-5479.0000022

Ozorhon, B., Arditi, D., Dikmen, I., \& Birgonul, M. T. (2011). Toward a multidimensional performance measure for international joint ventures in construction. Journal of Construction Engineering and Management, 137(6), 403-411. https://doi.org/10.1061/(ASCE)CO.1943-7862.0000314

Park, B. J., Srivastava, M. K., \& Gnyawali, D. R. (2014). Impact of coopetition in the alliance portfolio and coopetition experience on firm innovation. Technology Analysis \& Strategic Management, 26(8), 893-907. https://doi.org/10.1080/09537325.2014.913016

Quintana-García, C., \& Benavides-Velasco, C. A. (2004). Cooperation, competition, and innovative capability: a panel data of European dedicated biotechnology firms. Technovation, 24(12), 927-938.

https://doi.org/10.1016/s0166-4972(03)00060-9

Sarstedt, M., Henseler, J., \& Ringle, C. M. (2011). Multigroup analysis in partial least squares (PLS) path modeling: Alternative methods and empirical results. Advances in International Marketing, 22(1), 195-218.

https://doi.org/10.1108/s1474-7979(2011)0000022012

Schreiber, J. B., Nora, A., Stage, F. K., Barlow, E. A., \& King, J. (2006). Reporting structural equation modeling and confirmatory factor analysis results: a review. Journal of Educational Research, 99(6), 323-338.

https://doi.org/10.3200/joer.99.6.323-338

Shen, L. Y., Wu, G. W., \& Ng, C. S. (2001). Risk assessment for construction joint ventures in China. Journal of Construction Engineering and Management, 16(5), 607-619. https://doi.org/10.1061/(ASCE)0733-9364(2001)127:1(76)

Shen, L. Y., Lu, W. S., \& Yam, M. C. (2006). Contractor key competitiveness indicators: A China study. Journal of Construction Engineering and Management, 132(4), 416-424.

https://doi.org/10.1061/(ASCE)0733-9364(2006)132:4(416)

Sillars, D. N., \& Kangari, R. (2004). Predicting organizational success within a project-based joint venture alliance. Journal of
Construction Engineering and Management, 130(4), 500-508. https://doi.org/10.1061/(ASCE)0733-9364(2004)130:4(500)

Tetteh, M. O., \& Chan, A. P. C. (2019). Review of concepts and trends in international construction joint ventures research. Journal of Construction Engineering and Management, 145(10), 04019057.

https://doi.org/10.1061/(ASCE)CO.1943-7862.0001693

Tetteh, M. O., Chan, A. P., \& Nani, G. (2019). Combining process analysis method and four-pronged approach to integrate corporate sustainability metrics for assessing international construction joint ventures performance. Journal of Cleaner Production, 237, 117781.

https://doi.org/10.1016/j.jclepro.2019.117781

Tetteh, M. O., Chan, A. P. C., Darko, A., \& Nani, G. (2020). Factors affecting international construction joint ventures: a systematic literature review. International Journal of Construction Management. https://doi.org/10.1080/15623599.2020.1850203

Thomason, S. J., Simendinger, E., \& Kiernan, D. (2013). Several determinants of successful coopetition in small business. Journal of Small Business \& Entrepreneurship, 26(1), 15-28. https://doi.org/10.1080/08276331.2012.761800

Tidström, A., \& Rajala, A. (2016). Coopetition strategy as interrelated praxis and practices on multiple levels. Industrial Marketing Management, 58, 35-44.

https://doi.org/10.1016/j.indmarman.2016.05.013

Toor, S. R., \& Ogunlana, S. O. (2008). Critical COMs of success in large-scale construction projects: Evidence from Thailand construction industry. International Journal of Project Management, 26(4), 420-430.

https://doi.org/10.1016/j.ijproman.2007.08.003

Tse, D. K., Pan, Y., \& Au, K. Y. (1997). How MNCs choose entry modes and form alliances: The China experience. Journal of International Business Studies, 28(4), 779-805. https://doi.org/10.1057/palgrave.jibs.8490119

Union Internationale des Chemins de fer. (2018, June). High speed rail brochure. https://uic.org/IMG/pdf/uic_speed_2018_ph08_web.pdf

Union Internationale des Chemins de fer. (2020, February). High speed lines in the world. https://uic.org/

Wang, T., Tang, W., Qi, D., Shen, W., \& Huang, M. (2015). Enhancing design management by partnering in delivery of international EPC projects: Evidence from Chinese construction companies. Journal of Construction Engineering and Management, 142(4), 04015099.

https://doi.org/10.1061/(ASCE)CO.1943-7862.0001082

Wilhelm, M. M. (2011). Managing coopetition through horizontal supply chain relations: linking dyadic and network levels of analysis. Journal of Operations Management, 29(7-8), 663-676. https://doi.org/10.1016/j.jom.2011.03.003

Zhai, Z., Shan, M., \& Le, Y. (2020). Investigating the impact of governmental governance on megaproject performance: evidence from China. Technological and Economic Development of Economy, 26(2), 449-478.

https://doi.org/10.3846/tede.2020.11334

Zhang, L., Wong, W. F., \& Chen, P. H. (2010). Critical factors influencing learning effectiveness in international construction joint ventures. International Journal of Construction Management, 10(1), 87-100. https://doi.org/10.1080/15623599.2010.10773140

Zhang, N., Deng, X., Zhao, X., \& Chang, T. (2019). Exploring the sources of contractors' competitive advantage on international HSR construction projects. International Journal of Civil Engineering, 17(7), 1115-1129.

https://doi.org/10.1007/s40999-018-0373-1 
Zhang, N., Hwang, B., Deng, X., \& Niu, Y. (2020a). How to balance interfirm relationships? A case from high-speed railway industry. Journal of Business \& Industrial Marketing, 35(11), 1785-1799. https://doi.org/10.1108/jbim-09-2019-0389

Zhang, N., Hwang, B., Deng, X., \& Ning, Y. (2020b). Achieving transient competitive advantage in high-speed rail projects bidding: Sustainable development perspective. Sustainable Development, 28(6), 1738-1754. https://doi.org/10.1002/sd.2121

Zhao, Z. Y., \& Shen, L. Y. (2008). Are Chinese contractors competitive in international markets?. Construction Management and Economics, 26(3), 225-236.

https://doi.org/10.1080/01446190801905380

Zhao, X., Hwang, B. G., \& Yu, G. S. (2013). Identifying the critical risks in underground rail international construction joint ventures: Case study of Singapore. International Journal of Project Management, 31(4), 554-566.

https://doi.org/10.1007/s12205-019-0602-4
Zhao, X., Hwang, B. G., \& Phng, W. (2014). Construction project risk management in Singapore: Resources, effectiveness, impact, and understanding. KSCE Journal of Civil Engineering, 18(1), 27-36. https://doi.org/10.1007/s12205-014-0045-X

Zhao, X., Wu, P., \& Wang, X. (2018). Risk paths in BIM adoption: empirical study of China. Engineering, Construction and Architectural Management, 25(9), 1170-1187.

https://doi.org/10.1108/ecam-08-2017-0169

Zhou, Q., Deng, X., Jin, R., \& Chang, T. (2019). Analyzing the key drivers of contractors' temporary competitive advantage in the competition of international high-speed rail projects. KSCE Journal of Civil Engineering, 23(11), 4579-4591. https://doi.org/10.1007/s12205-019-0602-4

Zuo, J., Zhao, X., Nguyen, Q. B. M., Ma, T., \& Gao, S. (2018). Soft skills of construction project management professionals and project success factors: A structural equation model. Engineering, Construction and Architectural Management, 25(3), 425-442. https://doi.org/10.1108/ecam-01-2016-0016

\section{APPENDIX}

\section{Sample survey questionnaire}

\section{Basic Information}

\section{Your company or organization name}

\section{Your employer}

$\square$ Design Enterprise $\square$ Civil Engineering Enterprise $\square$ Manufacturing Enterprise

$\square$ Operation Enterprise $\square$ Design and civil engineering Enterprise $\square$ Other (please specify)

3. Your current work location : ? (If the work or project location is overseas, please fill in the form; if the location is China (mainland), you may not fill in the form);

\section{Your position in the project or enterprise:}

Project: $\square$ Senior Management (e. g. project chief, project manager) $\square$ Middle Management (e. g. department manager) $\square$ Junior Management (e.g. director or deputy director) $\square$ Ordinary Employee $\square$ Other (please indicate)

Enterprise: $\square$ Senior Management (e. g. general manager, deputy general manager) $\square$ Middle Management (e. g. department manager) $\square$ Junior Management (e. g. director or deputy director) $\square$ Ordinary Employee $\square$ Other (please indicate)

\section{How many years of work experience do you have?}

$\square<5$ years $\square 5-10$ years $\square 11-15$ years $\square 16-20$ years $\square>20$ years.

Based on your experience and knowledge, please evaluate the degree of influence of the listed factors on the coopetition strategy for the international joint ventures in high-speed projects. We welcome you to supplement the missing factors in the questionnaire.

The questionnaire uses the five-point Likert scale system, in which five-point system means: 1 - Very Unimportant; 2 - Relatively Unimportant; 3 - Neutral; 4 - Relatively Important; 5 - Very Important. 


\section{Please click only one choice for each factor}

\begin{tabular}{|l|l|c|c|c|c|c|}
\hline \multicolumn{1}{|c|}{ Macro Factors } & 1 & 2 & 3 & 4 & 5 \\
\hline F1 & Inter-state relations of IJVs members ${ }^{1}$ & $\square$ & $\square$ & $\square$ & $\square$ & $\square$ \\
\hline F2 & Domestic support for high-speed railway Contractors to enter the international market $^{\prime}$ & $\square$ & $\square$ & $\square$ & $\square$ & $\square$ \\
\hline F3 & Industry international reputation $^{2}$ & $\square$ & $\square$ & $\square$ & $\square$ & $\square$ \\
\hline & Firm Capability & 1 & 2 & 3 & 4 & 5 \\
\hline F4 & Financial capacity & $\square$ & $\square$ & $\square$ & $\square$ & $\square$ \\
\hline F5 & Technical level & $\square$ & $\square$ & $\square$ & $\square$ & $\square$ \\
\hline F6 & Corporate reputation ${ }^{3}$ & $\square$ & $\square$ & $\square$ & $\square$ & $\square$ \\
\hline & Management Leadership & 1 & 2 & 3 & 4 & 5 \\
\hline F7 & Support from senior managers & $\square$ & $\square$ & $\square$ & $\square$ & $\square$ \\
\hline F8 & Allocation of enterprise resources & $\square$ & $\square$ & $\square$ & $\square$ & $\square$ \\
\hline F9 & Inter-leadership relationships of IJVs members & $\square$ & $\square$ & $\square$ & $\square$ & $\square$ \\
\hline & Relationship Development & 1 & 2 & 3 & 4 & 5 \\
\hline F10 & Inter-organizational trust ${ }^{4}$ & $\square$ & $\square$ & $\square$ & $\square$ & $\square$ \\
\hline F11 & Target conformance level & $\square$ & $\square$ & $\square$ & $\square$ & $\square$ \\
\hline F12 & Cultural fit & $\square$ & $\square$ & $\square$ & $\square$ & $\square$ \\
\hline F13 & Previous cooperation experience & $\square$ & $\square$ & $\square$ & $\square$ & $\square$ \\
\hline F14 & Communication & $\square$ & $\square$ & $\square$ & $\square$ & $\square$ \\
\hline F15 & Long-term agreement & $\square$ & $\square$ & $\square$ & $\square$ & $\square$ \\
\hline & Organizational Structure & 1 & 2 & 3 & 4 & 5 \\
\hline F16 & Employee participation & $\square$ & $\square$ & $\square$ & $\square$ & $\square$ \\
\hline F17 & Setting up a professional working department & $\square$ & $\square$ & $\square$ & $\square$ & $\square$ \\
\hline F18 & Organizational inspiration & $\square$ & $\square$ & $\square$ & $\square$ & $\square$ \\
\hline & Project Management Capability & 1 & 2 & 3 & 4 & 5 \\
\hline F19 & Risk sharing mechanism & $\square$ & $\square$ & $\square$ & $\square$ & $\square$ \\
\hline F20 & Conflict resolution capability & $\square$ & $\square$ & $\square$ & $\square$ & $\square$ \\
\hline F21 & Contract integrity & $\square$ & $\square$ & $\square$ & $\square$ & $\square$ \\
\hline F22 & Learning climate & $\square$ & $\square$ & $\square$ & $\square$ \\
\hline
\end{tabular}

\footnotetext{
${ }^{1}$ The inter-state relations of JVs members refer to the relations among the home countries of IJVs members from different countries, including political relations, economic relations, diplomatic relations, cultural relations, military relations, etc.

${ }^{2}$ Industry international reputation refers to the recognition of domestic high-speed railway related technical standards in the international market.

${ }^{3}$ Corporate reputation refers to the ability of corporate behavior to gain social recognition and thereby complete value creation.

${ }^{4}$ Inter-organizational trust refers to the relationship of mutual trust between members of the IJVs.

${ }^{5}$ Learning climate refers to a good atmosphere for employees from various enterprises to learn from each other in the project department established by the IJVs.
} 